\title{
DIFFERENCE BETWEEN OF DESCRIPTION HEMATOGRAM AND HEART FUNCTION TEST ON PREECLAMPSIA AND ECLAMPSIA IN BANJARMASIN
}

\author{
$1^{\text {st }}$ Sismeri Dona ${ }^{1}, 2^{\text {nd }}$ Yayu Puji Rahayu ${ }^{2}$ \\ \{ sismeridonas2keb06@gmail.com ${ }^{1}$, rahayu.yp@gmail.com ${ }^{2\}}$ \\ *Departement of Midwifery, Faculty of Health, Sari Mulia University, Banjarmasin \\ *Corresponding author: sismeridonas2keb06@gmail.com
}

\begin{abstract}
Preeclampsia and eclampsia are pregnancy-specific syndromes that are characterized by increased blood pressure and are accompanied by persistent proteinuria with or without edema. to assess the presence of complications in preeclampsia and eclampsia hematogram and liver function tests were carried out in Banjarmasin. The purpose of this study was to determine the differences in hematogram and liver function tests in maternal with preeclampsia and eclampsia in Banjarmasin. The research method used was retrospective descriptive, data was collected using a checklist. In analyzing data with frequency distribution. The results showed that hematograms and liver function tests in patients with preeclampsia and eclampsia had no differences that ranged from normal values.
\end{abstract}

Keywords: Eclampsia, Hematogram, Liver function tests, Preeclampsia.

\section{Introduction}

According to WHO (World Health Organization) around the world every minute a woman dies due to complications related to pregnancy, childbirth, and childbirth. As many as $99 \%$ of maternal deaths due to childbirth or birth problems occur in developing countries. The ratio of maternal deaths in developing countries is the highest with 450 maternal deaths per 100,000 live births. Many maternal deaths are caused by preeclampsia and eclampsia [1]. MMR (Maternal Mortality Rate) in Indonesia in 2012 reached 359 per 100,000 births, which is still relatively high in ASEAN countries. Three main causes of maternal mortality in Indonesia in the field of obstetrics are bleeding (28\%), preeclampsia (24\%) and infections $(11 \%)$ [2].

Preeclampsia is a pregnancy-specific syndrome characterized by an increase in systolic blood pressure $\geq 140 / \geq 90 \mathrm{mmHg}$ that appears after week 20 and can persist for up to 6 weeks after delivery accompanied by proteinuria measured more than $300 \mathrm{mg} / 24$ hours or more than $30 \mathrm{mg}$ protein / dL (+1) persistently with or without edema. Eclampsia is a seizure event in pregnant women with preeclampsia that can be accompanied or without loss of 
consciousness not because of epilepsy or other neurological disorders. Gestational hypertension can develop into preeclampsia and eclampsia [3].

The most common complication of preeclampsia / eclampsia is HELLP syndrome which is most common in cells / organs such as blood (thrombocytopenia), liver (increased liver enzymes), and kidney (proteinuria). Therefore there are many abnormalities in the routine hematological picture in preeclampsia / eclampsia, including the number of erythrocytes, hemoglobin, hematocrit, platelet counts, count of leukocytes, liver function test images, namely the Glutamate Oxalacetate Transaminase (SGOT) and Serum Glutamate Pyruvate Transaminase (SGPT), and kidney, namely ureum and blood creatinine [3].

Hematogram tests should be performed on patients with preeclampsia and eclampsia and any abnormalities should be corrected immediately [4]. The hematogram tests required include the count of blood cells (CBC), urinalysis, prothrombin time electrolytes, liver function, partial thrombop / astin time. Sometimes creatinine and creatinin clearance checks are needed to anticipate kidney disorders [5].

The incidence of preeclampsia in the world according to WHO in 2012 ranged from $0.51 \%$ $38.4 \%$. The incidence of preeclampsia in developed countries ranges from $5-6 \%$ and eclampsia $0.1-0.7 \%[6]$.

The incidence of preeclampsia in Indonesia based on data from hospitals that reported the incidence of preeclampsia and eclampsia through SIRS (Hospital Information System) amounted to 8311 events this figure is lower than the estimation from the results of Riskesdas in 2010 stated that the incidence of preeclampsia / eclampsia was around 131,513 events. The preeclampsia / eclampsia incident based on Riskesdas illustrates the number of events in South Kalimantan ranked 7 out of 33 provinces in Indonesia [7].

The incidence of preeclampsia / eclampsia in South Kalimantan based on Riskesdas with a population of $<7$ million has an incidence of 4,161 with a percentage of $99.86 \%$, South Kalimantan ranks one of the four provinces with a population of $<7$ million and the lowest is in West Nusa Tenggara Province (NTT) with a percentage of 78.38\% [7].

\section{Research Method}

The study was conducted in the VK room Dr. H. Moch. Ansari Saleh Banjarmasin, South Kalimantan. This research used a descriptive retrospective method. This research was conducted by looking directly at the medical record in patients with preeclampsia and eclampsia.

The population in this study were women who had preeclampsia with an average count of January to March 2018 with a total of 93 with an average of 31 patients per month and women who had eclampsia with 33.

The sample in this study used a minimum sample with 31 samples from preeclampsia and 30 people from eclampsia in VK room Dr. H. Moch. Ansari Saleh Banjarmasin. Eclamptic sampling is a minimal sampling technique, where the lowest sample is 30, whereas preeclampsia sampling is done by using probability sampling and simple random sampling is used.

\section{Research Resulth}


The results of the study in the VK room of Dr. H Moch Ansari Saleh Banjarmasin Hospital on the Difference between Hematogram Images and Liver Function Tests in Pregnant Mothers with Preeclampsia and Eclampsia with a sample of 61. This study was conducted to see differences in the features of hematogram and liver function tests in pregnant women with preeclampsia and eclampsia in the VK room of Dr. H Moch Ansari Saleh Banjarmasin Hospital and obtained the results of the study based on the number of each hematogram results and based on the number of each liver function test from the mother with preeclampsia and eclampsia, as follows:

Table 1. Differences in hematogram images and liver function tests at Dr. H. Moch. Ansari Saleh Banjarmasin

\begin{tabular}{|c|c|c|c|c|}
\hline \multirow{2}{*}{ Hematogram } & \multicolumn{2}{|c|}{ Preeclampsia } & \multicolumn{2}{|c|}{ Eclampsia } \\
\hline & $\overline{\mathrm{F}}$ & $\%$ & $\mathrm{~F}$ & $\%$ \\
\hline \multicolumn{5}{|l|}{ Hemoglobin (gr/dL) } \\
\hline$<12$ & 9 & 29,03 & 8 & 26,67 \\
\hline $12-16$ & 16 & 51,61 & 16 & 53,33 \\
\hline$>16$ & 6 & 19,35 & 6 & 20 \\
\hline \multicolumn{5}{|l|}{ Leukosit $\left(\mathrm{mm}^{2}\right)$} \\
\hline$<3.200$ & 2 & 6,45 & 0 & 0 \\
\hline $3.200-10.000$ & 18 & 58,06 & 20 & 66,67 \\
\hline$>10.000$ & 11 & 35,48 & 10 & 33,33 \\
\hline \multicolumn{5}{|l|}{ Trombosit } \\
\hline$<170.000$ & 6 & 19,35 & 2 & 6,67 \\
\hline $170.000-380.000$ & 17 & 54,84 & 21 & 70 \\
\hline$>380.000$ & 8 & 25,81 & 7 & 23,33 \\
\hline Liver function tests & $\mathrm{F}$ & $\%$ & $\mathrm{~F}$ & $\%$ \\
\hline \multicolumn{5}{|l|}{$\overline{\text { SGOT (u/L) }}$} \\
\hline$\overline{<5}$ & 0 & 0 & 0 & 0 \\
\hline $5-34$ & 31 & 100 & 30 & 100 \\
\hline$>34$ & 0 & 0 & 0 & 0 \\
\hline \multicolumn{5}{|l|}{ SGPT (u/L) } \\
\hline$<5$ & 0 & 0 & 0 & 0 \\
\hline $5-35$ & 31 & 100 & 30 & 100 \\
\hline$>35$ & 0 & 0 & 0 & 0 \\
\hline
\end{tabular}

Based on table 1, it was found that from 61 samples including 31 samples in women with preeclampsia showed that the hematogram which consisted of $\mathrm{HB}$, leukocytes and platelets in this study was obtained in the highest $\mathrm{HB}$ value of $12-16 \mathrm{gr} / \mathrm{dL}$ as much as $51.61 \%$, leukocytes the highest was 3,200-10,000 mm3 with $58,06 \%$, the highest platelet count was 170,000-380,000 / Mel Blood was 54,84\% and the highest SGOT liver function test was at 5$34 \mathrm{u} / \mathrm{L} 100 \%$ and SGPT the most at a value of 5-35 u / L as much as 100\%. Whereas 30 mothers giving birth with eclampsia showed that hematogram images consisting of $\mathrm{HB}$, leukocytes and platelets in this study obtained the most $\mathrm{HB}$ values of $12-16 \mathrm{gr} / \mathrm{dL}$ as much as $53.33 \%$, the most leukocytes at values of 3,200-10,000 $\mathrm{mm} 3$ as many as $66,67 \%$, the most platelets at $170,000-380,000 /$ Mel Blood as much as $70 \%$ and the highest SGOT liver function test at 5-34 u / L as much as 100\% and the highest SGPT at the value of 5-35 u / L as many as $100 \%$ 


\section{Discuss}

Based on research conducted at Dr. H. Moch Ansari Saleh Banjarmasin on July 26, 2018 regarding differences in the picture of hematogram and liver function tests in women giving birth with preeclampsia and eclampsia in the VK room of Dr. H Moch Ansari Saleh Hospital Banjarmasin obtained the results of research on maternal women with preeclampsia it can be seen that the hematogram picture includes HB normal (12-16 gr / dL) is the most samples ie 16 samples $(51.61 \%)$ and high $\mathrm{HB}(>16 \mathrm{gr} / \mathrm{dL})$ is the fewest samples ie 6 samples $(19.35 \%)$, normal Leukocytes $(3,200-10,000)$ is the most samples, 18 samples $(58.06 \%)$ and low leukocytes $(<3,200 \mathrm{~mm} 2)$ are the fewest samples, 2 samples $(6.45 \%)$ and normal platelets $(170,000-380,000)$ are the most numerous samples ie 17 samples $(54.84 \%)$ and low platelets (<170,000 / Mel Blood) were the fewest samples, 6 samples $(19.35 \%)$ and the results of normal SGOT liver function tests (5-34) were the most samples, 31 samples $(100 \%)$ and normal SGPT (5-35) are samples el most is 31 samples (100\%). Whereas in 30 eclampsia samples, hematogram results including normal HB (12-16) were the most samples, 16 samples $(53.33 \%)$ and low HB (> $16 \mathrm{gr} / \mathrm{dL}$ ) were the least samples, 6 samples (20\%), Leukocytes normal $(3,200-10,000)$ is the most samples, 20 samples $(66.67 \%)$ and high leukocytes (> $10,000 \mathrm{~mm} 2)$ are the fewest samples, 10 samples $(33.33 \%)$ and normal platelets $(170,000$ $380,000)$ are the most samples namely 21 samples $(70 \%)$ and low platelets $(<170,000 / \mathrm{Mel}$ Blood) are the fewest samples ie 2 samples $(6.67 \%)$ and the results of normal SGOT liver function tests (5-34) are the most samples ie 30 samples ( 100\%) and normal SGPT (5-35) are the most samples, 30 samples $(100 \%)$.

Based on research conducted in the VK Room Dr. H. Moch Ansari Saleh Banjarmasin on the Difference between Hematogram and Liver Function Tests in Mothers with Preeclampsia and Eclampsia in the VK Room of RSUD Dr. H Moch Ansari Saleh Banjarmasin showed that there were differences in the features of hematogram and liver function tests in mothers with preeclampsia and eclampsia, seen from the results of research that has been done, from 61 samples including 31 samples in mothers with preeclampsia showed that the hematogram which consisted of $\mathrm{HB}$, leukocytes and platelets in this study obtained the most $\mathrm{HB}$ values of $12-16 \mathrm{gr} / \mathrm{dL}$ as much as $51.61 \%$, the most leukocytes at a value of $3,200-10,000 \mathrm{~mm} 3$ were $58.06 \%$, the most platelets were at 170,000-380,000 / Mel Blood as much as $54.84 \%$ and the highest SGOT liver function tests were at 5-34 as much as $100 \%$ and SGPT the most at a value of 5-35 as much as $100 \%$. Whereas 30 mothers giving birth with eclampsia showed that hematogram images consisting of HB, leukocytes and platelets in this study obtained the most $\mathrm{HB}$ values of $12-16 \mathrm{gr} / \mathrm{dL}$ as much as $53.33 \%$, the most leukocytes at values of $3,200-10,000 \mathrm{~mm} 3$ as many as $66,67 \%$, the most platelets at 170,000-380,000 / Mel Blood as much as 70\% and the highest SGOT liver function tests at 534 as much as $100 \%$ and the highest SGPT at the value of 5-35 as much as $100 \%$.

Based on the results of the study obtained the results of hematogram and liver function tests between patients with preeclampsia and eclampsia all within normal limits. This shows that the results of hematogram and liver function tests in preeclampsia are lower than in women with eclampsia so this study is in accordance with Yudi's theory (2011) stating that low hemoglobin levels in blood are known as anemia [8]. 
The results in accordance with the theory according to Shu (2012) states that in women with preeclampsia there is an increase but within normal limits on platelets, hemoglobin and hematocrit significantly, but the levels of SGOT / SGPT do not increase significantly. In eclampsia there is no increase in SGOT / SGPT if it is not accompanied by the incidence of HELLP syndrome.

The results of this study are supported by research conducted by Sumarni (2013) with the title Influence of Hemoglobin and Hematocrit Levels on Eclampsia in Pregnant Women with Severe Pre-Eclampsia in Rsud Margono Soekadjo Purwokerto in 2013 stating the results of the study found the suspected cause of preeclampsia suspected to be a disturbance in blood vessel endothelial function (cells lining the inside of blood vessels) that cause vasospasm of blood vessels (contraction of blood vessels muscles that cause the diameter of the blood vessel lumen shrink / shrink). Endothelial damage not only causes blockage of the placental blood vessels that causes the placenta to develop abnormally or is damaged, but also causes malfunctioning of various organs and leakage of capillaries which manifests in the mother by rapidly increasing maternal weight, swelling (sudden worsening of swelling in both legs), swelling of the hands and face), pulmonary edema, and / or hemoconcentration (hemoglobin / $\mathrm{Hb}$ levels greater than $13 \mathrm{~g} / \mathrm{dL}$ ). The presence of blood hemoconcentration causes an increase in hematocrit levels. So it can be concluded that increasing hemoglobin levels can increase hematocrit [9].

Another supportive study conducted by Kawuryan (2014) with the title Influence of Thrombocyte Levels and ALT / AST on Preeclampsia / Eclampsia states platelet levels are important laboratory parameters in preeclampsia / eclampsia. In this study, the highest preeclampsia platelets were obtained in the range of 150,000 - 450,000, 33 cases (91.6\%), which were within the normal range and eclampsia platelets in the range of more than $450,000,26$ cases $(85.8 \%)$. These results show that changes in platelet levels do not occur because of the possibility of the most cases, namely in the beginning of preeclampsia and in eclampsia an increase in the possibility of thrombocytosis that has led to other complications. Increased platelet levels occur after clinical symptoms and eclampsia complications arise and this shows the progression of preeclampsia. Distribution of cases of preeclampsia / eclampsia based on ALT / AST laboratory results. Maternal output, preeclampsia / eclampsia without other complications with a total of 19 cases and 8 cases for preeclampsia and eclampsia. Laboratory results of ALT / AST preeclampsia most complications at a value <33, namely 14 cases $(73.7 \%)$ and at the highest eclampsia at values $>65$, which is 10 cases $(53.2 \%)$. In this study the most results are AST within normal limits. This explains that the case in the study there were differences in platelet levels and ALT / AST. [10]

\section{Conclusion}

Conclusion of the results of the study that the data of hematogram and liver function tests in women with preeclampsia have lower values than those with eclampsia more than those with preeclampsia even though the most data shows that the results are in the normal category but still somewhat higher than those who did not suffer from preeclampsia or eclampsia. Researchers realize the results of this study are not only obtained based on hematogram and liver function tests, there may be other reasons such as urinalysis and creatinine examination. 


\section{Reference}

[1] Gafur, Abdul Z. Hubungan Antara Primigravida dengan Preeklampsia (2012).

[2] Depkes. Kesehatan Dalam Kerangka Sustainable Development Goals (SDGs). Jakarta: Departemen Kesehatan Indonesia (2015).

[3] Woo Yang L. S. Faktor - faktor yang Berhubungan Dengan Kejadian Preeklampsia di RSUD dr. Moewardi Surakarta (2015).

[4] William Obstetri. Gawat-Darurat Obstetri-Ginekologi \& Obstetri. Ginekologi Sosial untuk Profesi Bidan. Jakarta: EGC (2011).

[5] Situmorang, Tigor H, Damantalm, Y. Januarista, A. Sukri. Faktor- Faktor yang Berhubungan dengan kejadian preeklampsia pada ibu hamil di poli KIA RSU Anutapura Palu. Jurnal kesehatan Tadulako. 2.(1) (2014).

[6] Handayani, Reisty Ria, Asri, C., Adisasmita. Kejadian Komplikasi Maternal : Pelaporan di Rumah Sakit dan hasil Riskesdas di Indonesia tahun 2010. (2013).

[7] Yudi. Complete Blood Count (CBC). Jakarta: EGC (2011).

[8] Sumarni, S. d Pengaruh Kadar Hemoglobin Dan Hematokrit Terhadap Eklamsia Pada Ibu Hamil Dengan Pre Eklamsia Berat Di Rsud Margono Soekadjo Purwokerto Tahun 2013 (2013).

[9] Shu, MD. Preeklampsia. India: Jaypee Brothers Publishers (2012).

[10] Kawuryan SL. dengan judul Pengaruh Kadar Trombosit dan ALT/AST Pada Ibu Preeklamsi /Eklamsi (2014). 